\title{
CORRECTIONS
}

\section{Obituary: James Roberts}

In this obituary for James Roberts (BMJ 2011;343:d7226, doi:10. 1136/bmj.d7226) we mistakenly said that he died on 24 June 2011, when in fact he died on 24 July 2011. Our apologies.

Cite this as: BMJ 2011;343:d7813

๑ BMJ Publishing Group Ltd 2011 